\title{
Analyzing the Arterial Blood Gases: A Comprehensive Approach
}

\author{
Maithili Thakur
}

\begin{abstract}
The arterial blood gas analysis provides extensive and crucial information to the intensivist. It indicates the state of alveolar ventilation, the oxygenation, as well as the acid-base balance. It is an invaluable tool in expert hands. This review attempts to clarify the concepts related to respiratory and metabolic acid-base disturbances with several examples.

Keywords: Anion gap, Metabolic acidosis, Metabolic alkalosis, Oxygenation, Respiratory acidosis, Respiratory alkalosis.

Research and Innovation in Anesthesia (2020): 10.5005/jp-journals-10049-0074
\end{abstract}

\section{INTRODUCTION}

Understanding arterial blood gas (ABG) reports is a crucial task in determining the management of patients requiring intensive and continuous monitoring. They give us a deep insight to the oxygenation deficiencies to be differentiated from primary ventilatory deficiencies and primary metabolic acid-base abnormalities. Hence, learning to interpret them in a proper way becomes an essential agenda in any anesthesiologist's learning diary. ${ }^{1}$

The aims of doing a blood gas analysis are to detect the existence and intensity of oxygen- and carbon dioxide-related abnormalities in the blood levels and the degree of compensation in maintaining the acid-base equilibrium, thereby diagnosing the condition and planning their management.

The maintenance of potential hydrogen $(\mathrm{pH})$ equilibrium by the three physiological processes of alveolar ventilation, oxygenation, and acid-base balance is reflected through the ABG report. There is a strong interrelation of all these three processes.

\section{Alveolar Ventilation}

The maintenance of carbon dioxide $\left(\mathrm{CO}_{2}\right)$ levels reflected by arterial $\mathrm{CO}_{2}$ pressure $\left(\mathrm{PaCO}_{2}\right)$ depends on the production and excretion of $\mathrm{CO}_{2}$ via alveolar ventilation by the body. Thus, alveolar ventilation is best assessed by $\mathrm{PaCO}_{2}$. Normal $\mathrm{PaCO}_{2}$ is $35-45 \mathrm{~mm} \mathrm{Hg}$.

\section{Assessment of Oxygenation Status}

Pulse oximetry $\left(\mathrm{SpO}_{2}\right)$ and $\mathrm{ABG}$ analysis $\left(\mathrm{SaO}_{2}\right)$ are useful for measuring oxygen saturation and thereby evaluating the oxygenation status. They determine the arterial oxygen content better than the partial pressure of arterial oxygen $\left(\mathrm{PaO}_{2}\right)$. If the saturation shown by a pulse oximeter is less than $90 \%$ and the $\mathrm{PaO}_{2}$ is less than $60 \mathrm{~mm} \mathrm{Hg}$, the patient is termed hypoxemic. ${ }^{2}$

Whether the hypoxia occurs due to hypoventilation (due to increase in $\mathrm{PaCO}_{2}$ ) or due to deficiency in oxygenation can be determined by calculating an alveolar-arterial (A-a) oxygen gradient $\left(\mathrm{P}(\mathrm{A}-\mathrm{a}) \mathrm{O}_{2}\right)$. $^{3}$ The alveolar-arterial difference in partial pressure of $\mathrm{O}_{2}$ is $\mathrm{P}(\mathrm{A}-\mathrm{a}) \mathrm{O}_{2}$. The partial pressure of alveolar oxygen $\left(\mathrm{PAO}_{2}\right)$ can be computed using fractional inspired oxygen concentration $\left(\mathrm{FiO}_{2}\right)$, partial pressure of arterial $\mathrm{CO}_{2}\left(\mathrm{PaCO}_{2}\right)$, and barometric pressure while $\mathrm{PaO}_{2}$ is measured by $\mathrm{ABG}$.

$\mathrm{PAO}_{2}=\mathrm{FiO}_{2}(\mathrm{P}($ baro $)-\mathrm{P}(\mathrm{wv}))-\mathrm{PaCO}_{2} / \mathrm{R}=0.21(760-47)-$ $40 / 0.8=150-50=100 \mathrm{~mm} \mathrm{Hg}$
Department of Anesthesiology, HinduHrudaySamrat Balasaheb Thackeray Medical College and Dr RN Cooper Municipal General Hospital, Mumbai, Maharashtra, India

Corresponding Author:MaithiliThakur, Department of Anesthesiology, HinduHrudaySamrat Balasaheb Thackeray Medical College and $\mathrm{Dr}$ RN Cooper Municipal General Hospital, Mumbai, Maharashtra, India, Phone: +91 8369233147, e-mail: maithili_t@yahoo.com

How to cite this article: Thakur M. Analyzing the Arterial Blood Gases: A Comprehensive Approach. Res Inno in Anesth 2019;4(2):50-54.

Source of support: Nil

Conflict of interest: None

\section{$\mathrm{PaO}_{2}=90-100 \mathrm{~mm} \mathrm{Hg}$}

$\mathrm{P}(\mathrm{A}-\mathrm{a}) \mathrm{O}_{2}$ is used as an index for shunting and ventilationperfusion (V/Q) mismatch and is normally about $5-25 \mathrm{~mm} \mathrm{Hg}$. It is however affected by age and $\mathrm{FiO}_{2}$. A-a gradient $=\mathrm{Age} / 4+4$. So, it increases with increase in the age. For every $10 \%$ rise in $\mathrm{FiO}_{2}$, the A-a gradient rises by $5-7 \mathrm{~mm} \mathrm{Hg}$.

The $\mathrm{PaO}_{2} / \mathrm{PAO}_{2}$ ratio (independent of $\mathrm{FiO}_{2}$ ) can also be calculated. Normal values are 90-99/92.6-100 =0.8-1.0. Grading of this ratio is done as follows: $<0.25$ is critical shunt, $0.25-0.5$ is significant shunt, and $0.5-0.8$ is moderate shunt.

The $\mathrm{PaO}_{2} / \mathrm{FiO}_{2}$ ratio is important since the $\mathrm{PaO}_{2}$ value should always be correlated with the amount of oxygen received by the patient. For example, $\mathrm{FiO}_{2}$ of $20 \%$ gives $\mathrm{PaO}_{2}$ of $100 \mathrm{~mm} \mathrm{Hg}$. $\mathrm{FiO}_{2}$ 1.0 gives $\mathrm{PaO}_{2}$ of $500 \mathrm{~mm} \mathrm{Hg}$ in normal individuals.

The stepwise evaluation of hypoxemia is shown in Flowchart 1.

\section{Acid-Base Balance}

Potential hydrogen is defined as negative logarithm to base 10 of hydrogen ions measured in $\mathrm{nmol}$ per liter. The $\mathrm{pH}$ equilibrium can be maintained by the buffer system of the kidneys, lungs, and blood and is computed by the Henderson-Hasselbalch equation: $\mathrm{pH}=6.1+\log \mathrm{HCO}_{3}{ }^{-} / 0.3 \times\left[\mathrm{PaCO}_{2}\right]$. The Henderson equation has been simplified by Kassirer and Bliech as $\mathrm{H}^{+}=24 \times \mathrm{PCO}_{2} / \mathrm{HCO}_{3}{ }^{-4}$. Thus, maintaining $\mathrm{pH}$ within range of $7.35-7.45$ is the primary objective of regulating acid-base balance. Decrease in arterial $\mathrm{pH}$ $(\mathrm{pH}<7.35)$ is acidemia whereas rise in arterial $\mathrm{pH}(\mathrm{pH}>7.45)$ points 
Flowchart 1: Flow diagram showing approach to hypoxemic respiratory failure

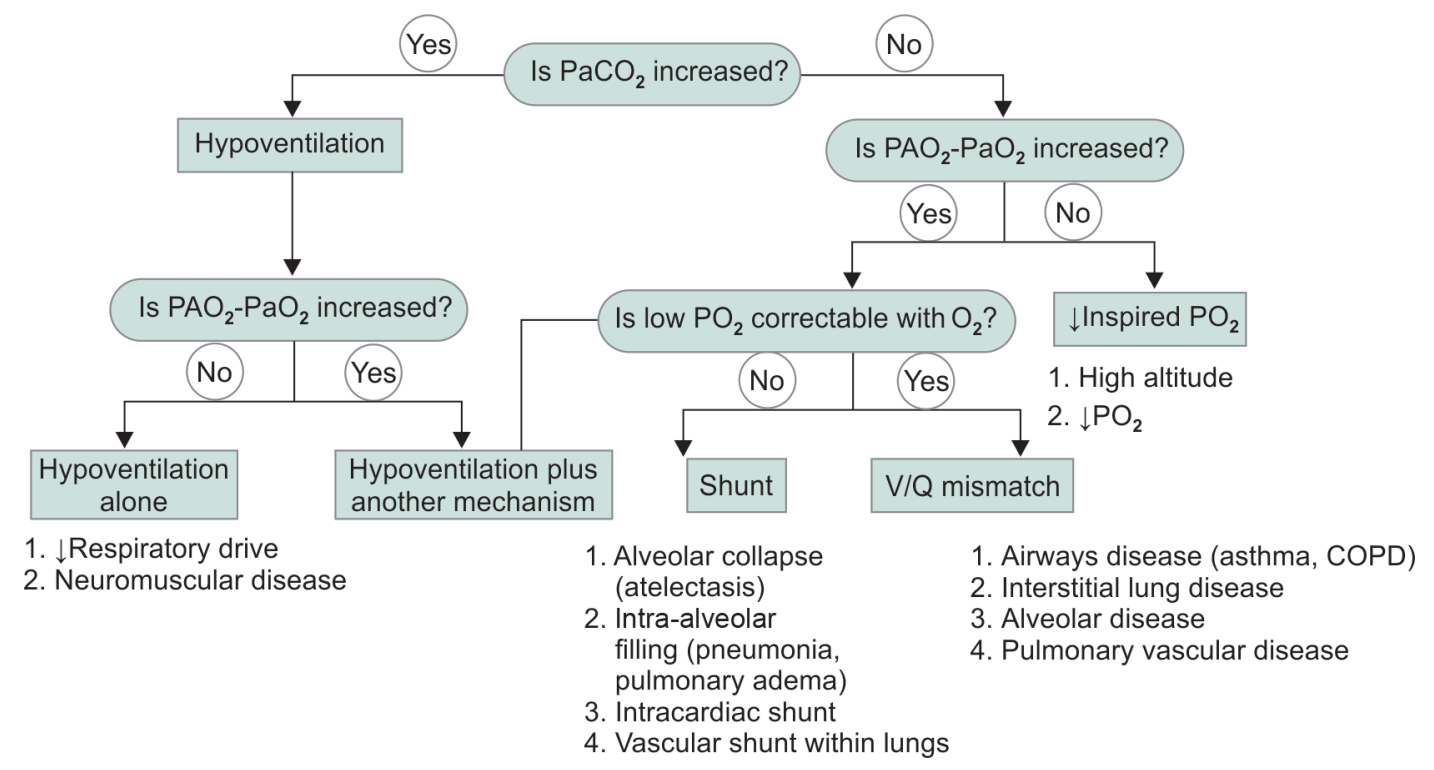

toward alkalemia. Thus, acidosis is defined as process tending to decline the $\mathrm{pH}$ by increasing $\mathrm{H}^{+}$or eliminating $\mathrm{HCO}_{3}{ }^{-}$, whereas the process causing surge in the $\mathrm{pH}$ on account of decreasing $\mathrm{H}^{+}$or rise of $\mathrm{HCO}_{3}{ }^{-}$is termed alkalosis.

\section{Respiratory and Metabolic Conditions}

Primary modifications in ventilation lead to respiratory acidosis or alkalosis due to excessive removal or accumulation of $\mathrm{CO}_{2}$. Metabolic conditions cause acidosis or alkalosis by alterations in the bicarbonate ions concentration.

\section{Compensation}

Compensation of primary acid-base disorder is done either by the lungs or kidneys. The respiratory system compensates for the metabolic changes due to deviations in $\mathrm{HCO}_{3}{ }^{-}$(metabolic acidosis or alkalosis) while kidneys compensate for fluctuations in $\mathrm{CO}_{2}$ (respiratory acidosis/alkalosis), which take around 2-5 days.

\section{Simple vs Mixed Acid-Base Disorder}

Simple acid-base disorder consists of only a primary single process of either acidosis or alkalosis whereas mixed acid-base disorder may have more than one acid-base disorder coexisting together.

In metabolic conditions, movement of $\mathrm{pH}$ and $\mathrm{HCO}_{3}{ }^{-}$is in same direction whereas in respiratory conditions the movement of $\mathrm{pH}$ and $\mathrm{PaCO}_{2}$ is in opposite direction. In simple disorders, the movement of $\mathrm{HCO}_{3}{ }^{-}$and $\mathrm{PaCO}_{2}$ is in same direction while in mixed disorders, fluctuations of $\mathrm{HCO}_{3}{ }^{-}$and $\mathrm{PaCO}_{2}$ are in opposite directions (Table 1).5,6

While evaluating for the acid-base status, the $\mathrm{pH}$ values range between 7.35 and 7.45; $\mathrm{PaCO}_{2}$ ranges between 35 and $45 \mathrm{~mm} \mathrm{Hg}$ and $\mathrm{HCO}_{3}{ }^{-}$values range between 22 and $26 \mathrm{mEq} / \mathrm{L}$. For calculation purposes, the base is taken as 7.40 for $\mathrm{pH}, \mathrm{PaCO}_{2}$ is taken as $40 \mathrm{~mm}$ $\mathrm{Hg}$, and $24 \mathrm{mEq} / \mathrm{L}$ for $\mathrm{HCO}_{3}{ }^{-7,8}$

The stepwise approach to the ABG Analysis ${ }^{4}$ was given by Narins and Emmett and modified by Morganroth in 1991. ${ }^{9}$
Table 1: Features of primary acid-base disorders

\begin{tabular}{lllll}
\hline Disorder & \multicolumn{3}{c}{ Primary responses } & \multicolumn{2}{c}{ Compensatory responses } \\
\hline Metabolic acidosis & $\uparrow\left[\mathrm{H}^{+}\right]$ & $\downarrow \mathrm{pH}$ & $\downarrow \mathrm{HCO}_{3}{ }^{-}$ & $\downarrow \mathrm{PaCO}_{2}$ \\
Metabolic alkalosis & $\downarrow\left[\mathrm{H}^{+}\right]$ & $\uparrow \mathrm{pH}$ & $\uparrow \mathrm{HCO}_{3}^{-}$ & $\uparrow \mathrm{PaCO}_{2}$ \\
Respiratory acidosis & $\uparrow\left[\mathrm{H}^{+}\right]$ & $\downarrow \mathrm{pH}$ & $\uparrow \mathrm{HCO}_{3}^{-}$ & $\uparrow \mathrm{HCO}_{3}^{-}$ \\
Respiratory alkalosis & $\downarrow\left[\mathrm{H}^{+}\right]$ & $\uparrow \mathrm{pH}$ & $\downarrow \mathrm{HCO}_{3}^{-}$ & $\downarrow \mathrm{HCO}_{3}^{-}$ \\
\hline
\end{tabular}

- Step 1. Evaluate if the patient has alkalosis or acidosis using the arterial $\mathrm{pH}$. Low $\mathrm{pH}(<7.35)$ is acidosis, if associated with low $\mathrm{HCO}_{3}{ }^{-}$is metabolic acidosis; high $\mathrm{PaCO}_{2}$ is respiratory acidosis. High pH (>7.45) is alkalosis, if associated with high $\mathrm{HCO}_{3}{ }^{-}$is metabolic alkalosis. Low $\mathrm{PaCO}_{2}$ is respiratory alkalosis.

- Step 2. Based on $\mathrm{PaCO}_{2}$ and serum $\mathrm{HCO}_{3}{ }^{-}$levels, check if there is a primary respiratory or metabolic disruption. $\mathrm{pH}$ moves in the same direction as $\mathrm{PaCO}_{2} / \mathrm{HCO}_{3}{ }^{-}$in case of metabolic conditions. $\mathrm{pH}$ moves in the opposite direction as $\mathrm{PaCO}_{2} / \mathrm{HCO}_{3}{ }^{-}$in case of respiratory conditions.

- Step 3. In case of a primary respiratory disorder, evaluate whether it is chronic or acute. This can be done by checking $\Delta \mathrm{H}^{+} /$ $\triangle \mathrm{PaCO}_{2}<0.3$ indicating chronic condition, $>0.8$ indicating acute condition, while $0.3-0.8$ indicates acute or chronic condition.

- Steps 4 and 5. In metabolic disorders, evaluate if the compensation by the respiratory system is adequate or not. In respiratory disorders, evaluate if compensation by the metabolic system is adequate or not (Table 2).

- Step 6. Check for the oxygenation status $\left(\mathrm{PaO}_{2}\right.$ and $\left.\mathrm{SaO}_{2}\right)$-if there is hypoxemia or not?

- Step 7A. In case of metabolic acidosis, calculate the anion gap (AG).

$\mathrm{AG}=\mathrm{Na}^{+}-\left(\mathrm{Cl}^{-}+\mathrm{HCO}_{3}{ }^{-}\right)$normal $<12$ and osmolar gap. In case of severe hypoalbuminemia, $A G$ should be corrected by $A G c=A G+$ $\{(4-[$ Albumin] $) \times 2.5\}$.

- Step 7B. In high anion gap metabolic acidosis (HAGMA), compute the sum of bicarbonate ions $\left(\mathrm{HCO}_{3}{ }^{-}\right)$and the change in anion gap $(\triangle \mathrm{AG})$ to check for coexisting metabolic imbalances. $\triangle \mathrm{AG}=\left[\mathrm{HCO}_{3}^{-}\right]+(\mathrm{AG}-12)$ 
Table 2: Compensation of simple acid-base imbalance

\begin{tabular}{|c|c|c|}
\hline Simple acid-base imbalance & Compensation & Formula \\
\hline Metabolic acidosis & $\mathrm{PaCO}_{2}$ decreases $1.2 \mathrm{~mm} \mathrm{Hg}$ per $1.0 \mathrm{mEq} / \mathrm{L}$ drop in $\mathrm{HCO}_{3}^{-}$ & $\begin{array}{l}\text { Expected } \mathrm{PaCO}_{2}=\left[\left(1.5 \times \mathrm{HCO}_{3}^{-}\right)+8\right] \pm 2 \\
\text { (Winter's formula) }\end{array}$ \\
\hline Metabolic alkalosis & $\mathrm{PaCO}_{2}$ rises $0.7 \mathrm{~mm} \mathrm{Hg}$ per $1.0 \mathrm{mEq} / \mathrm{L}$ rise in $\mathrm{HCO}_{3}{ }^{-}$ & Expected $\mathrm{PaCO}_{2}=\left[\left(0.7 \times \mathrm{HCO}_{3}^{-}\right)+21\right] \pm 1.5$ \\
\hline Respiratory acidosis & {$\left[\mathrm{HCO}_{3}^{-}\right]$increases } & \\
\hline Acute & {$\left[\mathrm{HCO}_{3}^{-}\right]$increases $1.0 \mathrm{mEq} / \mathrm{L}$ per $10 \mathrm{~mm} \mathrm{Hg}$ rise of $\mathrm{PaCO}_{2}$} & $\Delta \mathrm{HCO}_{3}^{-}=\Delta \mathrm{PaCO}_{2} \times 0.1 \pm 3$ \\
\hline Chronic (3-5 days) & {$\left[\mathrm{HCO}_{3}{ }^{-}\right]$increases $4 \mathrm{mEq} / \mathrm{L}$ per $10 \mathrm{~mm} \mathrm{Hg}$ rise of $\mathrm{PaCO}_{2}$} & $\Delta \mathrm{HCO}_{3}^{-}=4\left(\Delta \mathrm{PaCO}_{2} \times 0.1\right)$ \\
\hline Respiratory alkalosis & {$\left[\mathrm{HCO}_{3}^{-}\right]$decreases } & \\
\hline Acute & {$\left[\mathrm{HCO}_{3}{ }^{-}\right]$decreases $2.0 \mathrm{mEq} / \mathrm{L}$ per $10 \mathrm{~mm} \mathrm{Hg}$ fall of $\mathrm{PaCO}_{2}$} & $\Delta \mathrm{HCO}_{3}{ }^{-}=2\left(\Delta \mathrm{PaCO}_{2} \times 0.1\right)$ \\
\hline Chronic & {$\left[\mathrm{HCO}_{3}{ }^{-}\right]$decreases $5.0 \mathrm{mEq} / \mathrm{L}$ per $10 \mathrm{~mm} \mathrm{Hg}$ fall of $\mathrm{PaCO}_{2}$} & $\Delta \mathrm{HCO}_{3}{ }^{-}=5\left(\Delta \mathrm{PaCO}_{2} \times 0.1\right)$ \\
\hline
\end{tabular}

If $>24$, consider additional hidden metabolic alkalosis. If $<24$, consider a hidden nonanion gap metabolic acidosis.

We can also calculate Delta ratio ${ }^{10,11}$ in case of HAGMA:

Delta ratio $=$ Increase in $\mathrm{AG} /$ decrease in $\mathrm{HCO}_{3}{ }^{-}$

Delta ratio $<1$ suggests a greater decrease in $\mathrm{HCO}_{3}{ }^{-}$than expected from the change in $A G$, i.e., additional nonanionic gap metabolic acidosis

Delta ratio ranging between 1 and 2 suggests HAGMA.

Delta ratio $>2$ suggests a less decrease in $\mathrm{HCO}_{3}{ }^{-}$than expected, i.e., additional metabolic alkalosis

- Step 7C. In case of nonanion gap acidosis, calculate the urinary anion gap that is necessary to differentiate between renal and nonrenal causes.

If compensation is as per calculation, it is a single acid-base disorder. If compensation is less than or greater than calculated expected value, then it is mixed acid-base problem.

\section{Metabolic Acidosis}

The pathophysiological causes of metabolic acidosis ${ }^{11}$ include: (1) $\mathrm{HCO}_{3}{ }^{-}$loss either due to renal or gastrointestinal tract (GIT) causes; (2) greater formation of nonvolatile acids, exogenous acids, lactates, ketoacids, and poisons; and (3) fall in renal acid secretion.

Causes of HAGMA include: (1) lactic acidosis; (2) diabetic ketoacidosis, alcoholic ketoacidosis, and starvation; (3) chronic renal failure; (4) rhabdomyolysis; (5) salicylate toxicity, methanol toxicity, and ethylene glycol toxicity.

Causes of normal AG metabolic acidosis (NAGMA): (1) $\mathrm{HCO}_{3}{ }^{-}$ loss due to GIT causes-biliary or pancreatic drainage, diarrhea, ketoacidosis during treatment, renal-proximal (type II) renal tubular acidosis (RTA), urinary diversions (ureterosigmoidostomy); (2) reduced renal acid excretion: renal failure, hyperkalemia (type IV) RTA, distal (type I) RTA; (3) miscellaneous: ammonium chloride $\left(\mathrm{NH}_{4} \mathrm{Cl}\right)$ therapy, $\mathrm{HCl}$ therapy (treatment of severe metabolic alkalosis), hyperalimentation, and cholestyramine ingestion.

Diagnosing cause of metabolic acidosis:

Plasma osmolality $=2\left[\mathrm{Na}^{+}\right]+[\mathrm{Gluc}] / 18+[\mathrm{BUN}] / 2.8$. Plasma osmolality gap is defined as the difference between the calculated and measured plasma osmolality.

In HAGMA:

If the plasma osmolality gap is more than $15-20 \mathrm{mOsm} / \mathrm{kg}$, then it shows presence of high osmolar substances like alcohol in the blood.

Ketones and hyperglycemia indicate diabetic ketoacidosis while ketones with normal glucose point to alcoholism and starvation. Serum lactate levels more than 2 indicate lactic acidosis.

\section{In NAGMA:}

Urine AG (UAG) is calculated. If positive UAG, then it indicates RTA; urine $\mathrm{pH}>5.5$ indicates type I RTA. If $\mathrm{pH}<5.5$ and high $\mathrm{K}^{+}$, it indicates type IV RTA; if $\mathrm{pH}<5.5$ and low potassium $\left(\mathrm{K}^{+}\right)$, it indicates type II RTA.

If negative UAG, the urine osmolality gap is calculated. If increased it's due to iatrogenic acid gain and if normal it's due to GIT causes.

Example 1: Patient comes with diabetic ketoacidosis at 0 hours at presentation. $\mathrm{pH} 7.06, \mathrm{CO}_{2}=10.3, \mathrm{HCO}_{3}{ }^{-}=6.1, \mathrm{Na}^{+} / \mathrm{Cl}^{-} 142 / 106$

- $\mathrm{pH}$ acidemia, primary condition metabolic with $\mathrm{pH}$ and $\mathrm{HCO}_{3}{ }^{-}$ both decreased

- $\mathrm{AG}=142-(106+6.1)=30 \uparrow \uparrow=$ HAGMA

- Compensation for metabolic acidosis: Winter's formula: Expected $\mathrm{CO}_{2}=(1.5 \times 6)+8=17$, but actual value $10<17$, indicating respiratory alkalosis (hyperventilation)

- Delta ratio $=\mathrm{AG}-12 / \mathrm{HCO}_{3}{ }^{-}-24=18 / 18=1$, no non-AG acidosis ( $\mathrm{Cl}^{-}$normal)

Thus, patient has HAGMA with respiratory alkalosis.

Same patient after 6 hours of treatment with insulin and saline, $\mathrm{pH} 7.22, \mathrm{CO}_{2}=24, \mathrm{HCO}_{3}{ }^{-}=10.2, \mathrm{Na}^{+} / \mathrm{Cl}^{-} 140 / 120$

- $\mathrm{pH}=$ acidemia, primary condition metabolic with $\mathrm{pH}$ and $\mathrm{HCO}_{3}{ }^{-}$ both decreased

- $A G=140-130=10$, now normal indicating NAGMA

- Metabolic acidosis compensation: Expected $\mathrm{CO}_{2}=(1.5 \times 10)+$ $8=23$ matches the measured $\mathrm{CO}_{2}$ (Winter's formula). Thus, compensation is adequate.

- Delta $\mathrm{AG}=(\mathrm{AG}-12)+$ measured $\mathrm{HCO}_{3}{ }^{-}=2+10=12<24$, indicating hidden NAGMA $\left(\mathrm{Cl}^{-} 120\right)$. Delta ratio which is the ratio of difference in $A G$ and bicarbonates $=(A G-12) /\left(\mathrm{HCO}_{3}{ }^{-}-24\right)=$ $2 / 14<1$.

With saline, hyperchloremic acidosis sets in. Thus, the patient now has NAGMA owing to the treatment. Ketoacids are being cleared (AG $\downarrow$ ), thus indicating a good response. Only $\mathrm{HCO}_{3}{ }^{-}$will not indicate adequacy of response.

Treatment of metabolic acidosis includes treating underlying cause, $\mathrm{HCO}_{3}{ }^{-}$therapy as per the formula $0.5 \times$ weight $(\mathrm{kg}) \times \mathrm{HCO}_{3}{ }^{-}$ deficit ( $\mathrm{mEq} / \mathrm{L}$ ). The objective is to raise the $\mathrm{pH}$ to $>7.2$ and $\mathrm{HCO}_{3}{ }^{-}>$ $10 \mathrm{mEq} / \mathrm{L}$.

\section{Metabolic Alkalosis}

Metabolic alkalosis is commonly (up to $50 \%$ of all disorders) associated with significant mortality.

Pathophysiological causes of metabolic alkalosis are the following: ${ }^{11}$ 
(1) $\mathrm{HCO}_{3}{ }^{-}$accumulation: massive blood transfusion, giving large amounts of $\mathrm{HCO}_{3}{ }^{-}$, ingestion (milk-alkali syndrome); (2) $\mathrm{H}^{+}$loss: GIT-loss of gastric secretions, chloride losing diarrheal diseases; renal: mineralocorticoid excess, diuretics (loop/thiazide), Bartter's syndrome, high-dose intravenous penicillin, post-chronic hypercapnia, hypercalcemia; (3) $\mathrm{H}^{+}$movement into cellshypokalemia, refeeding. Most in $\mathrm{ICU}$ are $\mathrm{Cl}^{-}$responsive ( urinary $\mathrm{Cl}^{-}<15 \mathrm{mEq} / \mathrm{L}$ ) due to vomiting, nasogastric suction, diuretics, laxative, and volume depletion. $\mathrm{Cl}^{-}$resistant (urinary $\mathrm{Cl}^{-}>25$ $\mathrm{mEq} / \mathrm{L}$ ) due to severe hypokalemia and high aldosterone.

Example 2: A 70-year-old male with history of poor oral intake associated with areflexia and weakness. $\mathrm{pH} 7.54 \uparrow, \mathrm{CO}_{2} 54 \uparrow, \mathrm{HCO}_{3}{ }^{-}$ $44, \mathrm{Na}^{+} / \mathrm{K}^{+} / \mathrm{Cl}^{-} 145 / 2.1 / 86$

- $\mathrm{pH}=$ alkalemia, condition being metabolic since both $\mathrm{pH}$ and $\mathrm{HCO}_{3}{ }^{-}$high

- $\mathrm{AG}=145-(86+44)=15$ normal

- Expected $\mathrm{CO}_{2}=0.7 \times \mathrm{HCO}_{3}{ }^{-}+21 \pm 2=0.7 \times 44+21 \pm 2=51.8$ \pm 2 , which is seen as per reading.

- Diagnosis is severe metabolic alkalosis due to severe hypokalemia $\left(\mathrm{K}^{+}=1.9\right)$.

Treatment: Immediate goal of therapy is partial correction of the alkalosis. The objective is reducing $\mathrm{pH}$ less than 7.55 and decreasing $\mathrm{HCO}_{3}{ }^{-}$less than $40 \mathrm{mEq} / \mathrm{L}$.

$\mathrm{Cl}^{-}$responsive type metabolic alkalosis is the most severe form. Treating the causes responsible for chloride and volume depletion. Administration of 3-5 L of $150 \mathrm{mEq} / \mathrm{L}$ sodium chloride should be done in patients with established signs of volume contraction. In case of chloride-resistant metabolic alkalosis, chloride should be repleted as potassium chloride. For metabolic alkalosis due to mineralocorticoid excess, spironolactone, which is a $\mathrm{K}^{+}$-sparing diuretic, proves beneficial.

\section{Respiratory Acidosis}

Acute respiratory acidosis is caused by obstruction in elimination of $\mathrm{CO}_{2}$ : (1) ventilation-related causes, airway obstruction like aspiration, bronchospasm (severe), laryngospasm; pulmonary edema; (2) perfusion-related causes: cardiac arrest, pulmonary thromboembolism; (3) restricted chest wall: tension pneumothorax, hemothorax, flail chest; (4) musculoskeletal system: myasthenia gravis crisis, hypokalemia; (5) failure of mechanical ventilator and other problems like (a) central nervous system (CNS): trauma, stroke, drugs (anesthetics, sedatives); (b) peripheral nerves: neurotoxins (OPC, tetanus, botulism), cervical cord injury, skeletal muscle relaxants (succinyl choline, curare, pancuronium and allied drugs, aminoglycosides)

Causes of chronic respiratory acidosis are obstruction in elimination of $\mathrm{CO}_{2}$ like (1) ventilation: interstitial lung disease, chronic obstructive pulmonary disease; (2) restricted chest wall movement: muscular dystrophy, polymyositis, etc., and (1) CNS: chronic trauma, obesity hypoventilation syndrome, brain malignancies, myxoedema, (2) peripheral nerves: diaphragmatic paralysis, poliomyelitis, multiple Sclerosis.

Example 3: A 21-year-old female presented with history of dyspnea and wheezing for 5 days. She was tachypneic with central cyanosis and bilateral wheezing present. Chest $\mathrm{X}$-ray showed tubular heart with hyperinflated lung fields. $\mathrm{pH}=7.31, \mathrm{CO}_{2}=64, \mathrm{HCO}_{3}{ }^{-}=30$, $\mathrm{PaO}_{2}=68 \mathrm{~mm} \mathrm{Hg}, \mathrm{Na}^{+} / \mathrm{Cl}^{-}=136 / 98$

- $\mathrm{pH}=7.31$ with increased $\mathrm{CO}_{2}$, hence dominant disorder is respiratory acidosis. Condition is chronic due to 5 days.
- $\mathrm{AG}=136-(98+30)=8$, which is normal.

- Compensation $=\Delta \mathrm{HCO}_{3}{ }^{-}=0.4 \times \Delta \mathrm{PaCO}_{2}=0.4 \times 24=9.6, \mathrm{HCO}_{3}{ }^{-}$ $=24+9.6=33.2$ compensation is adequate.

The diagnosis is chronic respiratory acidosis.

Treatment of respiratory acidosis is correction of underlying cause, appropriate oxygenation preventing subduing of respiratory drive, and avoid rapid correction of increased $\mathrm{PaCO}_{2}$ to avoid posthypercapnic metabolic alkalosis (seizures, arrhythmias).

\section{Respiratory Alkalosis}

Causes of respiratory alkalosis comprises of head trauma, brain tumor, cerebrovascular accidents and other causes like pain, anxiety, fever, and peripheral respiratory stimulation like pulmonary V/Q imbalance, pulmonary shunts, hypovolemia, heights, diffusion problems, and miscellaneous causes like drugs-NSAIDs, progesterone, thyroid hormone, catecholamines, gram-ve sepsis, pregnancy, heat exposure, mechanical ventilation.

Example 4: 15-year-old boy presented with complaints of difficulty in breathing and upper abdominal discomfort for 3 hours. On examination per abdomen and respiratory system are normal except for hyperventilation. $\mathrm{pH}=7.5, \mathrm{PaCO}_{2}=26 \mathrm{~mm} \mathrm{Hg}, \mathrm{HCO}_{3}{ }^{-}=$ $20 \mathrm{mEq}, \mathrm{PaO}_{2}=100 \mathrm{~mm} \mathrm{Hg}, \mathrm{Na}^{+} / \mathrm{Cl}^{-}=137 / 99$.

- $\mathrm{pH}=7.5$ with decreased $\mathrm{CO}_{2}$, hence dominant disorder is respiratory alkalosis.

- $\mathrm{AG}=137-(99+20)=18$, which is raised. AG is slightly raised in respiratory alkalosis. Since it occurred only 3 hours back, it is an acute respiratory alkalosis.

- Compensation $\Delta \mathrm{HCO}_{3}=0.2 \times \Delta \mathrm{PaCO}_{2}=0.2 \times 14=2.8, \mathrm{HCO}_{3}{ }^{-}=$ $24-2.8=21.2$; compensation is adequate. Diagnosis is acute respiratory alkalosis.

Treatment of respiratory alkalosis consists of treatment of underlying cause, administration of $\mathrm{O}_{2}$. If $\mathrm{pH}>7.55$, the patient is sedated and paralyzed and put on ventilator.

\section{In Mixed Acid-base Disorders}

Step 1. Determine the primary component as explained previously depending on the direction of $\mathrm{pH}, \mathrm{pCO}_{2}, \mathrm{HCO}_{3}{ }^{-}$.

Step 2. Calculate $\mathrm{AG}=\mathrm{Na}-\left(\mathrm{Cl}+\mathrm{HCO}_{3}\right), n=12 \pm 4$.

Step 3A. Calculate expected $\mathrm{CO}_{2}$ if metabolic.

Metabolic acidosis: $\mathrm{CO}_{2}=\left(1.5 \times \mathrm{HCO}_{3}{ }^{-}\right)+8$

Metabolic alkalosis: $\Delta \mathrm{CO}_{2}=0.7 \times \Delta \mathrm{HCO}_{3}{ }^{-}$

3B. Calculate expected $\mathrm{HCO}_{3}{ }^{-}$if respiratory

$\Delta \mathrm{HCO}_{3}{ }^{-}=0.1 \times \Delta \mathrm{CO}_{2}$ (respiratory acidosis)

$0.2 \times \Delta \mathrm{CO}_{2}$ ( if respiratory alkalosis)

$0.4 \times \Delta \mathrm{CO}_{2}$ (if chronic respiratory acid/alkalosis)

Step 4. Calculate delta ratio $=(\mathrm{AG}-12) /\left(\mathrm{HCO}_{3}-24\right)$

Examples of mixed acid-base disorders

Example 5: A 68-year-old male taking diuretics for congestive heart failure admitted for lobar pneumonia: $\mathrm{pH} 7.62 \uparrow, \mathrm{CO}_{2} 32 \downarrow, \mathrm{HCO}_{3}{ }^{-}=$ $34 \uparrow, \mathrm{Na}^{+} / \mathrm{K}^{+} 142 / 96$

- $\mathrm{pH}=$ Primary alkalemia, metabolic alkalosis due to high $\mathrm{HCO}_{3}{ }^{-}$

- $\mathrm{AG}=142-129=13$ normal

- Since metabolic is primary check for respiratory compensation

- Expected $\mathrm{CO}_{2}=0.7 \times \mathrm{HCO}_{3}{ }^{-}+21=0.7 \times 9+21 \pm 2=44.8 \pm 2$

- But actual $\mathrm{CO}_{2} 32<<44.8$ indicates that there is also associated respiratory alkalosis (hyperventilation)

- Diagnosis is metabolic alkalosis (loss of $\mathrm{K}^{+}$and $\mathrm{Cl}^{-}$due to diuretics) + respiratory alkalosis 
Example 6: A 60-year-old male, known case of hypertension, underwent emergency abdominal exploration and he suffered intraoperative infarct and arrest pH 7.27 $\downarrow, \mathrm{CO}_{2} 66 \uparrow, \mathrm{HCO}_{3}{ }^{-}=20 \mathrm{Na}^{+}$/ $\mathrm{K}^{+}=138 / 102$

- $\mathrm{pH}=$ acidemia along with increased $\mathrm{CO}_{2}$ levels indicating respiratory acidosis

- $\mathrm{AG}=138-(102+20)=16$ normal. Since, it was emergency abdominal exploration, the changes were acute.

- $\Delta \mathrm{HCO}_{3}{ }^{-}=0.1 \times \Delta \mathrm{CO}_{2}=0.1 \times 26=2.6$

Expected $\mathrm{HCO}_{3}{ }^{-}=24+2.6=26.6$ but actual $20<26$ indicating metabolic acidosis developing due to poor circulation. Hence diagnosis is post-arrest respiratory acidosis and developing metabolic acidosis.

Example 7: A 75-year-old male with severe abdominal pain and shock, pH 7.35, $\mathrm{CO}_{2} 22, \mathrm{HCO}_{3}{ }^{-}=14 \downarrow \downarrow, \mathrm{Na}^{+} / \mathrm{K}^{+} / \mathrm{Cl}^{-} 137 / 4.9 / 107$

- $\mathrm{pH}$ tends to acidemia $=$ metabolic acidosis due to low $\mathrm{HCO}_{3}{ }^{-}$

- $\mathrm{AG}=(137+5)-(107+13)=12(\mathrm{NAGMA})$

- Respiratory compensation Winter formula $\mathrm{CO}_{2}(1.5 \times 14)+8=29$

but actual $\mathrm{CO}_{2} 22<29$, there is overcompensation of ventilation resulting in respiratory alkalosis.

- Urine AG and Urine Osmolarity Gap needs to be calculated.

Thus, the diagnosis is non-anion gap metabolic acidosis secondary to shock + respiratory alkalosis secondary to hyperventilation due to pain.

Example 8: A 45-year-old male known case of chronic renal failure admitted to the intensive care unit with severe vomiting $\mathrm{pH} 7.40, \mathrm{PaCO}_{2}=42, \mathrm{HCO}_{3}{ }^{-}=22, \mathrm{Na}^{+} / \mathrm{K}^{+} / \mathrm{Cl}^{-} 150 / 3.8 / 99$, serum creatinine 8.7

- $\mathrm{pH}=$ normal

- $\mathrm{AG}=150-(99+22)=29 \uparrow \uparrow(\mathrm{HAGMA})$

- Respiratory compensation $\mathrm{CO}_{2}=(1.5 \times 24)+8=44$, compensation is adequate
$\Delta$ Ratio $=(\mathrm{AG}-12) /\left(\mathrm{HCO}_{3}{ }^{-}-24\right)=15 / 2>2$-presence of metabolic alkalosis. Thus, the diagnosis is HAGMA (uremic) $+M$ alkalosis (vomiting), thus normalizing the $\mathrm{pH}$ values.

\section{Conclusion}

Thus, we conclude that knowledge about the triad of oxygenation, ventilation, and acid-base status helps us in thorough analysis of ABG. However, ABG results are only meaningful when inferred taking into account patients' symptomatology, pathophysiology, and treatment in details. Hence, emphasis is to treat the patient and not the ABG.

\section{References}

1. Gattinoni L, Pesenti A, Matthay M. Understanding blood gas analysis. Intensive Care Med 2018;44(1):91-93. DOI: 10.1007/s00134-017-4824-y.

2. Barthwal MS. Analysis of arterial blood gases - a comprehensive approach. J Associat Physic India 2004;52:573-577.

3. Castro D, Keenaghan M. Arterial blood gas. [updated 2020 mar 21]. In: StatPearls [Internet]. Treasure Island (FL): StatPearls Publishing; 2020.

4. Rao SM, Nagendranath V. Arterial blood gas monitoring. Indian J Anaesth 2002;46(4):289-297.

5. Sood P, Paul G, Puri S. Interpretation of arterial blood gas. Indian J Crit Care Med 2010;14(2):57-64. DOI: 10.4103/0972-5229.68215.

6. Buche V. Arterial blood gases: a simplified bedside approach. J Neonat Biol 2014;3(04):153. DOI: 10.4172/2167-0897.1000153.

7. Cowley NJ, Owen A, Bion JF. Interpreting arterial blood gas results. Br Med J 2013;346(jan16 1):f16. DOI: 10.1136/bmj.f16.

8. Larkin BG, Zimmanck RJ. Interpreting arterial blood Gases Successfully. Associat Reg Nurs JI 2015;102(4):343-354. DOI: 10.1016/j. aorn.2015.08.002; quiz 355-7.

9. Morganroth ML. Six steps to acid-base analysis: clinical applications. J Crit III 1990;5(5):460-469.

10. Salem MM, Mujais SK. Gaps in the anion gap. Arch Intern Med 1992;152(8):1625-1629. DOI: 10.1001/archinte.1992.00400200063011.

11. Black RM. Metabolic acidosis and metabolic alkalosis. In: Irwin RS, Rippe JM. Intensive Care Medicine. 5th ed., Philadelphia: Lippincott Williams Wilkins; 2003. 852-864. 